International Young Scientist Conference "Developments in Optics and Communications, 2010"

\title{
OPTICALLY INDUCED SURFACE RELIEF GRATINGS IN POLYMER FILMS DOPED WITH SULPHONYL GROUP CONTAINING AZOBENZENE
}

\author{
E. Laizane ${ }^{1}$, D. Gustina ${ }^{2}$, K. Kundzins ${ }^{1}$, I. Muzikante ${ }^{1}$, J. Teteris ${ }^{1}$ \\ ${ }^{1}$ Institute of Solid State Physics, University of Latvia, \\ 8 Kengaraga Str., Riga, LATVIA \\ ${ }^{2}$ Latvian Institute of Organic Synthesis, \\ 21 Aizkraukles Str., Riga, LATVIA \\ e-mail: elina.laizane@gmail.com
}

\begin{abstract}
In holography, more attractive have become azobenzene compounds doped in a polymer matrix (host-guest polymer film) or chemically attached to the polymer. Azobenzene molecules exhibit reversible photoisomerization between trans- and cisisomers which can form a surface relief grating in the films. The authors investigate the holographic recording and formation of surface relief gratings in a host-guest polymer film with two original azobenzene compounds. Holographic recording with $325 \mathrm{~nm}$ laser light was performed in host-guest polymer films with the host being polymethylmetacrylate (PMMA) and the guest $-15 \mathrm{wt} \%$ azobenzene molecules (A-45 or A-48). In both cases an increase in the diffraction efficiency at the beginning of the process could be related to the trans-cis-photoisomerization, while the second increase - to the formation of surface relief gratings. The systems with A-45 molecules reach a diffraction efficiency of $0.7 \%$, and with A-48 molecules - of $0.24 \%$. Also, the depth of surface relief gratings is greater in the films with A-45 (35 to $45 \mathrm{~nm}$ ) than in those with A-48 (4 to $6 \mathrm{~nm}$ ) molecules.

Key words: azobenzene compounds, photoisomerization, holographic recording, surface relief gratings, host-guest polymer film.
\end{abstract}

\section{INTRODUCTION}

Azobenzene compounds are promising in the holographic recording due to the photoisomerization processes. The azobenzene molecules have two isomers, of trans- and cis-form. Photoisomerization occurs when a molecule transforms from a trans- to a cis-isomer by light irradiation, and from a cis- to a trans-isomer - by light irradiation or thermally. During the photoisomerization process the azobenzene molecules change their geometry (spatial volume), refraction indices and dipole moment $[1,2]$. This process can be used also for recording the surface relief gratings (SRGs). It is an admitted point of view that the trans-cis-trans isomerization is followed by molecular reorientation and mass transport $[2,3]$.

For the SRG recording two possible systems exist. First of them is a hostguest polymer film where the host is polymer and the guest - azobenzene compound. The second is a polymer film in which the azobenzene moieties are 
attached in a side or in the main chain of the polymer. In both cases the movement of azobenzene molecules or moieties can induce mass transport in the thin film [2, 3], owing to which SRGs can form. The systems differ in the recording speed and the diffraction grating efficiency. Although the dynamics of SRG recording appears comparable in both systems, the surface-relief recorded after saturation was shown to be about seven times greater in the polymer with attached molecules than in the host-guest system [4]. Dye grafting onto the polymer chain appears thus as an important parameter for improvement of the surface-relief grating formation. However the host-guest system is easier to produce and the concentration of guest molecules is one of the parameters which can be changed to obtain higher efficiencies.

In this paper, we will report on the holographic recording and formation of surface relief gratings in a host-guest polymer film of polymethylmetacrylate (PMMA) doped with original azobenzene molecules, 6-[4-(4-Dicyclohexylsulfamoyl-phenylazo)-phenoxy]-hexanoic acid (A-45), 6-\{4-[4-(Hexyl-phenylsulfamoyl)-phenylazo]-phenoxy $\}$-hexanoic acid (A-48) (see Fig. 1). We have observed a reversible trans/cis photoisomerization of compound A-45 in solutions and in Langmuir-Blodgett multilayers on irradiation with alternating UV (360 nm) and visible $(450 \mathrm{~nm})$ light. In the solution of A-45 compound in $\mathrm{CHCl}_{3}$ with concentration $1.0 \times 10^{-4} \mathrm{M}$ the optical density time response of the main absorption band at $360 \mathrm{~nm}$ caused by photoisomerization lasts about $50 \mathrm{~s}$. The reversible process induced by irradiation with visible light is slower, i.e. $13 \mathrm{~min}$ [5]. According to the results of previous studies, we have investigated the possibility of recording the surface relief gratings in a host-guest polymer film of azobenzene derivative A-45. In order to investigate the influence of the molecular structure on the recording process the azobenzene derivative A- 48 is chosen. The azobenzene derivatives contain various bulky hydrophobic groups: N,N-dicyclohexyl- moiety in the molecule A-45 and N-phenyl-N-hexylamine moiety in the molecule A-48. The holographic recording in host-guest polymer films is performed at wavelength $325 \mathrm{~nm}$, which corresponds to the short-wave side of the main trans-isomer absorption band.

\section{EXPERIMENTAL}

\section{Sample preparation}

The host material was PMMA (molecule mass 440000 from SigmaAldrich). Solutions of PMMA and A-45 or A-48 in chloroform were prepared and ultrasonically mixed for $15 \mathrm{~min}$. The amounts of compounds were chosen so as to obtain host-guest films with a concentration of azobenzene molecules of $15 \mathrm{wt} \%$.

Before the use as a substrate a quartz glass was cleaned with chloroform. The PMMA/A-45 and PMMA/A-48 samples were prepared by the spin coating method. The speed and acceleration were $400 \mathrm{rpm}$ and $100 \mathrm{rpm} / \mathrm{s}$, respectively, the time was $40 \mathrm{~s}$. The thickness of the films was $2 \mu \mathrm{m}$. The samples were dried for 5 days at room temperature $\left(\sim 22^{\circ} \mathrm{C}\right)$ in a dark place to reduce the chloroform amount. 

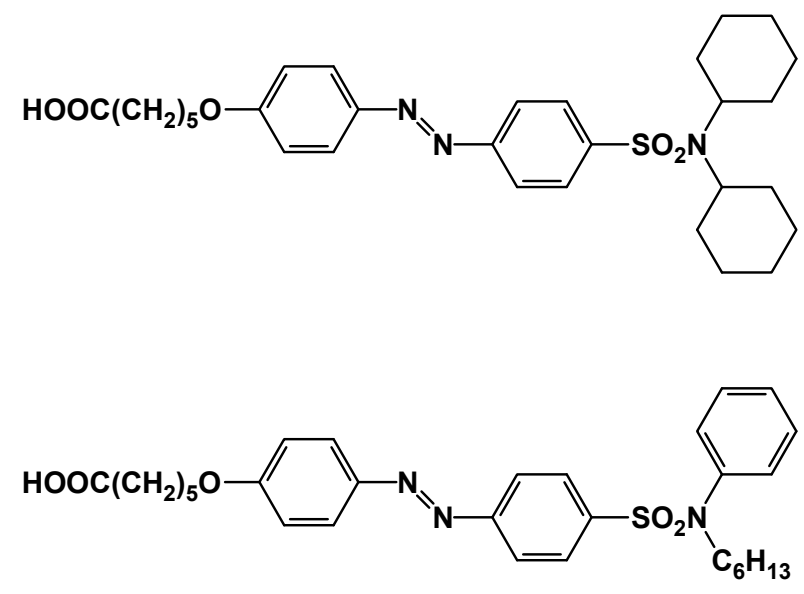

Fig. 1. The azobenzene molecule structure.

\section{Experimental equipment}

The setup for holographic recording is shown in Fig. 2. A He-Cd laser (RL) with wavelength $325 \mathrm{~nm}$ was used as the source of recording light. The beam splitter (BS) divides the light into two $40 \mu \mathrm{W}$ intensity beams with a diameter of $3 \mathrm{~mm}$. A half-wave plate (HP) adjusts the light beams to $p$-polarization. The angle between the recording beam and the normal of the sample was $\theta=9.4^{\circ}$, which means that the grating was recorded with period $1 \mu \mathrm{m}$. The diffraction efficiency (DE) of gratings was measured with a diode laser $676 \mathrm{~nm}(\mathrm{ReL})$ light to registered diffracted light intensity. The $\mathrm{DE}(\eta)$ for gratings was defined as $\eta=I_{d} / I_{0}$, where $I_{d}$ is the intensity of the diffracted beam, and $I_{0}$ is the intensity of the readout beam. The diffracted beam on transmission mode was measured by photodiode (PD) connected to the register equipment.

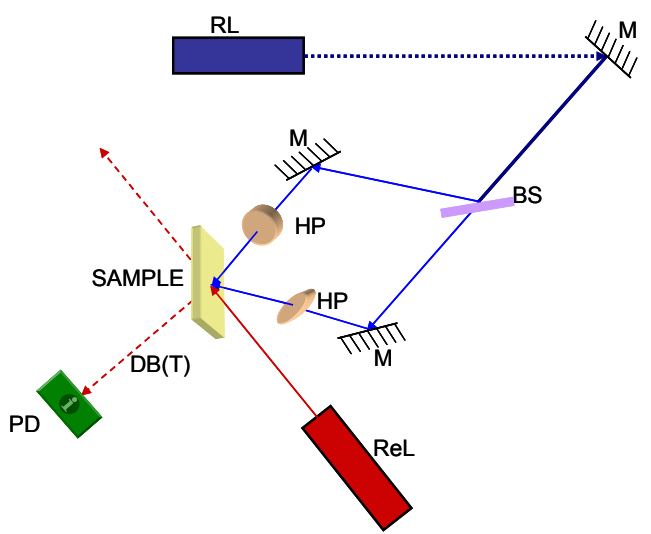

Fig. 2. The holographic recording setup: $\mathrm{RL}$ - recording laser, $\mathrm{M}$ - mirror, $\mathrm{BS}$ - beam splitter, $\mathrm{HP}$ - half-wave plate, PD - photodiode.

A Stand Alone "Смена" atomic force microscope was used to measure the profile of recorded diffraction gratings in the host-guest polymer film. In the measurements, non-contact ultra-sharp silicon cantilevers (NSCH11 series) were used. The radius of the needle was $30 \mathrm{~nm}$. 
The optical images of samples were obtained by a Nikon Eclipse L150 optical microscope

The absorption spectrum of samples was measured with an Ocean Optics HR4000 spectrometer.

\section{RESULTS AND DISCUSSION}

It is shown that the trans-isomer of azobenzene A-45 in chloroform solution exhibits the main absorption band at $363 \mathrm{~nm}$ and a shoulder at $440 \mathrm{~nm}$. The cisisomer shows two spectrally well-separated bands - the increased band at $440 \mathrm{~nm}$ and the very diminished and broad band at about $360 \mathrm{~nm}$. The optical densities of these bands correlate with the densities of trans- and cis-isomers [5]. Experimentally, in the absorption spectra of the host-guest polymer films it was possible to obtain only the absorption band of trans-isomer. The values of absorption bands for cis-isomer are usually calculated [1,6]. This means that in the case of cisisomer we can use approximate values of the absorption bands. The absorption spectrum of azobenzene A-48 in chloroform solution is very similar to that of azobenzene A-45.

The absorption spectra of the host-guest polymer film of PMMA/A-45 and PMMA/A-48 are shown in Fig. 3. The main absorption band of trans-isomer $(363 \mathrm{~nm})$ and the spectrally separated shoulder connected to $c i s$-isomer $(440 \mathrm{~nm})$ are visible.
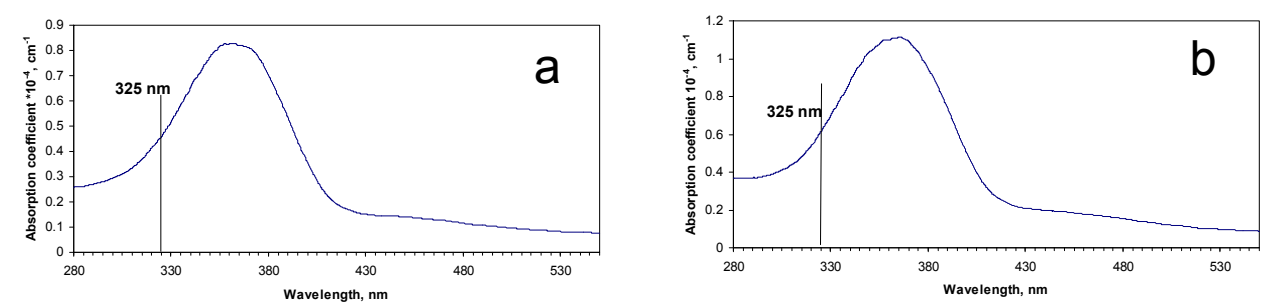

Fig.3. Absorption spectra of the PMMA host-guest polymer film with $15 \mathrm{wt} \%$ concentration of A-45 (a) and A-48 (b) azobenzene molecules.

The azobenzene molecules A-45 and A-48 have strong dipole moments both in trans- and cis-isomers. According to the RHF ab initio calculations with the basis set $6-31 \mathrm{G}^{* *}$ by Gaussian G09W software package, the dipole moment of an azobenzene A-45 trans-isomer is $5.11 \mathrm{D}$, and that of a cis-isomer - 7.14 D [7]. This means that such dipoles tend to associate and could make aggregates in a polymer matrix. Such aggregates will behave differently from isolated azobenzene molecules and could influence the holographic recording. In the optical images (magnification 1000 $\times$ ) of virgin PMMA/A-45 and PMMA/A-48 host-guest polymer films no aggregations were observed. We therefore could use these films for recording the diffraction gratings.

The holographic recording was performed with a laser at wavelength $325 \mathrm{~nm}$, which corresponds to the short wavelength side of the trans-isomer absorption band. At this wavelength we could expect that the trans-to-cis photoisomerization prevents excessive cis-to-trans isomerization. 
The kinetics of the first-order diffraction efficiency in transmission at the initial state of exposure in first $500 \mathrm{~s}$ of the recording is shown in Fig. 4 (curves $a$ and $b$ for PMMA/A-45 and PMMA/A-48 films, respectively). At the beginning of recording the maximum of diffraction efficiency was observed.

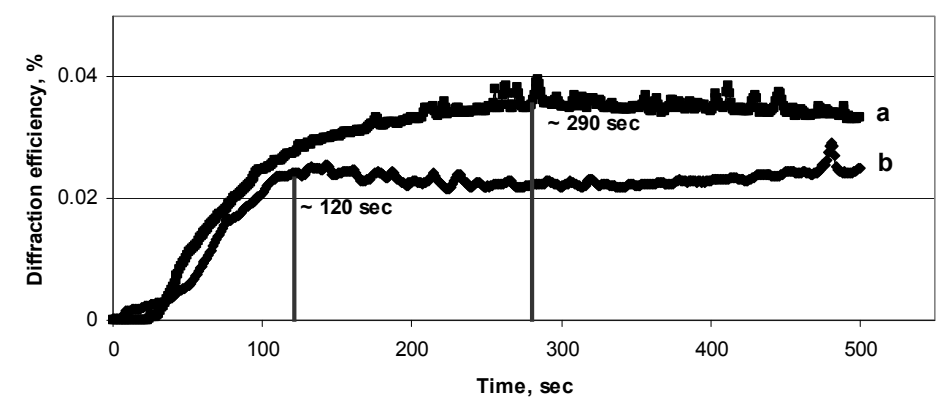

Fig. 4. Kinetics of the diffraction efficiency in first $500 \mathrm{~s}$ of the holographic recording of PMMA/A-45 host-guest polymer film $(a)$ and the PMMA/A-48 host-guest polymer film $(b)$. The concentration of azobenzene molecules is $15 \mathrm{wt} \%$.

The increase in diffraction efficiency could be related to the creation of double refraction in the sample [8]. In our case it is less probable, since the system is centro-symmetrical. The rapid DE increase at the initial state of recording can be explained with formation of cis- and trans-isomer gratings. In the illuminated area the molecules switch to cis-isomer, while in the non-illuminated area they stay in the trans-form. As we can see from Fig. 4, for a polymer film with A-45 molecules the DE maximum is $0.035 \%$ (reached after $290 \mathrm{~s}$ ) and for that with A-48 molecules it is $0.025 \%$ (reached after $120 \mathrm{~s}$ ).

A fast DE increase in the initial state (with a relative maximum and minimum seen in Fig. 4) was followed by a slow final increase to higher DE values up to saturation (Fig. 5). This should be related to formation of SRGs. The movements of molecules in the system are induced by the changes of molecular geometry. An additional influence of such a movement could be exerted by changes of dipole moments going from trans- to cis-isomer. Due to dipole-dipole interaction, the azobenzene molecules that are nearest to the polymer chain may change their position. Here it should be noted that the molecular transport occurs at room temperature, whereas the glass transition temperature of the studied films is close to $100^{\circ} \mathrm{C}$. It is widely accepted (see, e.g. [2]) that transport of the molecules is possible due to a local plasticization experienced by the azobenzene molecules that undergo trans-cis-trans isomerization followed by molecular reorientation and mass transport. We may assume that under modest light intensities employed in our experiments the thermal effects are negligible and the mass transport is entirely light-driven.

The maximum values for diffraction efficiency and saturation time were $0.7 \%$ and $75 \mathrm{~min}$, respectively, for PMMA/A-45 films, and $0.24 \%, 58 \mathrm{~min}$ for PMMA/A-48 films (see Fig. 5, $a$ and $b$ ). Formation of SRGs in films with $15 \mathrm{wt} \%$ A-45 molecules gives larger diffraction efficiencies but it lasts longer in comparison with the films of $15 \mathrm{wt} \%$ A-48 molecules. A similar situation was observed at the beginning of recording (see Fig. 4, $a$ and $b$ ). 


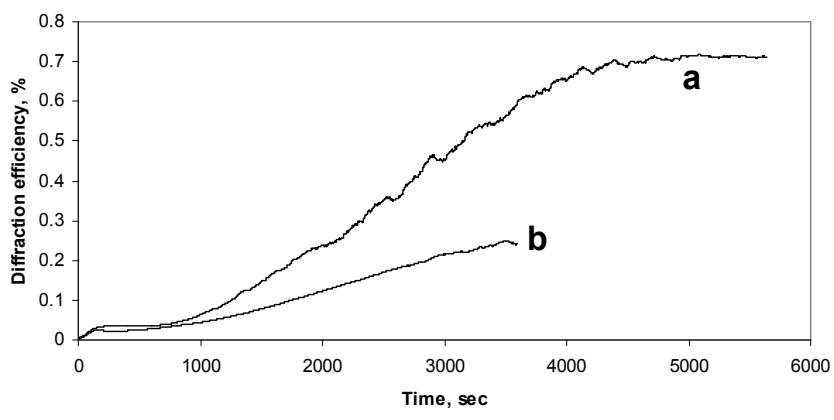

Fig. 5. Full kinetics of the diffraction efficiency during holographic recording in host-guest polymer films of PMMA/A-45 (a) and PMMA/A-48 (b).

After recording, the samples were examined using the optical microscope. The regular diffraction gratings were well-observed in an $85 \times 60 \mu \mathrm{m}$ area for the sample with A-45 molecules. Unfortunately, such a good grating is not forming in the films with A-48 molecules.

The atomic force microscope shows that in the PMMA thin film with A-45 azobenzene molecules the depth of surface relief grating is from 35 to $45 \mathrm{~nm}$ (see Fig. $6 a$ ) and for the film with A-48 molecules - only 4 to $6 \mathrm{~nm}$ (see Fig. $6 b$ ). This explains why we were unable to see a diffraction grating in the optical microscope for the sample with A-48 molecules.
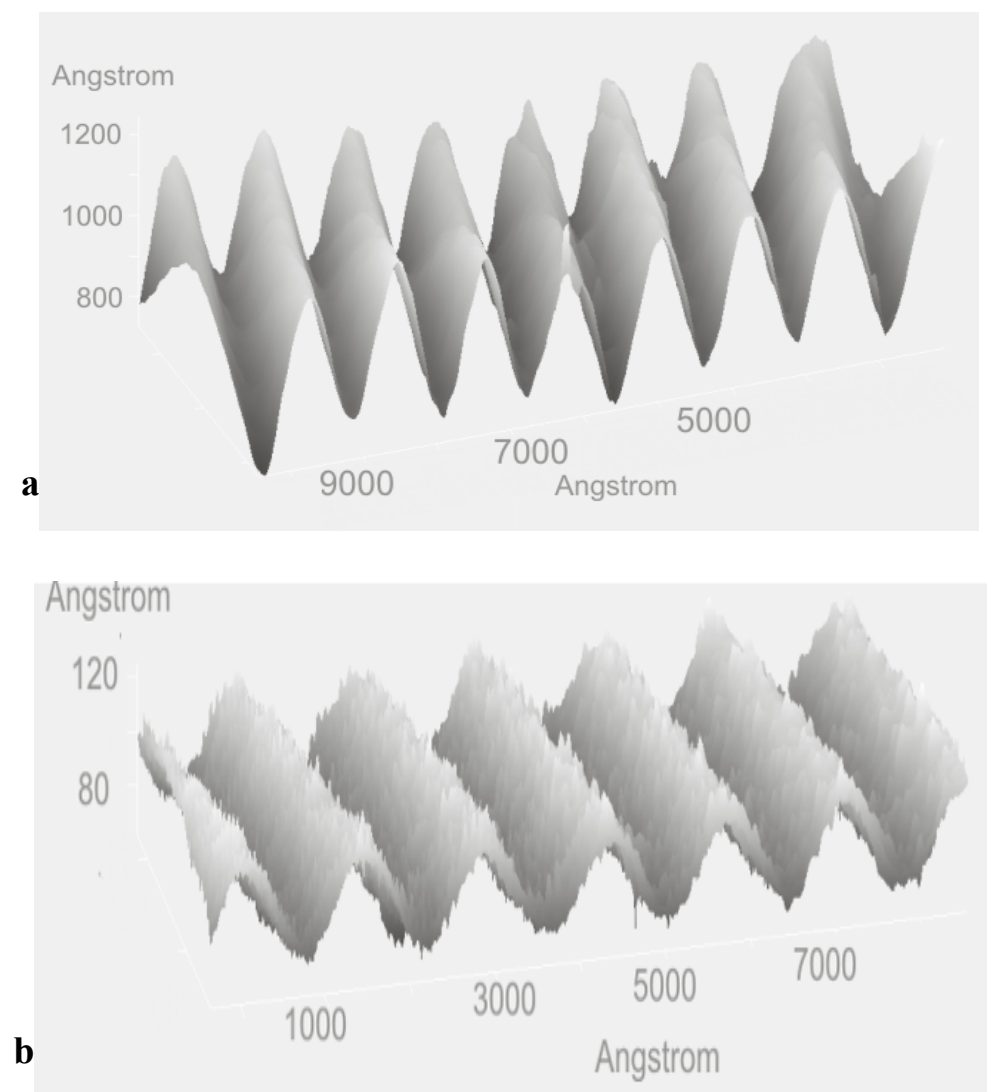

Fig. 6. AFM images of the surface relief grating in host-guest polymer films of PMMA/A-45 $(a)$ and PMMA/A-48 (b). 
Such a large difference between the depths of surface relief gratings for these azobenzene compounds could be explained by the structures of the molecules. As is mentioned in Ch. 1, azobenzene derivatives contain various bulky hydrophobic groups: N,N-dicyclohexyl- moiety in the molecule A-45 and N-phenyl-N-hexylamine moiety in the molecule A-48. It is known that the cyclohexane rings are not planar, so a ring inversion, which involves rotation about single bonds of cyclic conformers, takes place [9]. At the same time, the A-48 molecule has a phenyl ring whose structure is planar and rigid. Such differences of the end groups may influence the packing, reorientation of the molecules and interaction between a molecule and the polymer in a polymer matrix. This could be one of the reasons why an A-48 molecule photoisomerizes harder in solid surrounding in comparison with an A-45 molecule. Another explanation is that the interaction of the molecule which has flexible cyclohexane rings (A-45) and a rigid phenyl ring (A-48) with the polymer causes different mass transport of both molecules and polymer during the holographic recording.

The recorded surface relief gratings are stable in time. After six months the depths of the gratings have decreased only $10 \%$.

\section{CONCLUSION}

The holographic recording in host-guest polymer films with incorporated A-45 or A-48 molecules has been performed at wavelength $325 \mathrm{~nm}$, which corresponds to the short-wave side of the main trans-isomer absorption band. At this wavelength a feasible explanation may be the trans-to-cis photoisomerization process. Nevertheless, simultaneously a reverse process (cis-to-trans photoisomerization) occurs, which arises due to the very diminished and broad cis-isomer band in the spectral region $300-360 \mathrm{~nm}$ and due to thermal influence. We may assume that the quantum efficiency of trans-to-cis photoisomeization exceeds that of the reverse process. For more feasible explanation, recording of the surface relief gratings with different wavelengths is advisable. For the host-guest polymer films with incorporated A-45 molecules the time of reaching the saturation of diffraction efficiency is $\sim 1.3$ times longer, but the DE value is more than 2.5 times larger as compared to the host-guest polymer films with incorporated A-48 molecules. The depth of recorded surface relief gratings is larger for host-guest polymer films with A-45 molecules (35 to $45 \mathrm{~nm}$ ) as compared to those with A-48 molecules (4 to $6 \mathrm{~nm}$ ). This can be explained by different moieties in the molecules. The cyclohexane rings in an A-45 molecule are not planar, therefore a ring inversion, which involves rotation about the single bonds of cyclic conformers, takes place. At the same time, the A-48 molecule has a phenyl ring with a planar and rigid structure. Such differences of the end groups may influence the packing and reorientation of the molecules in a polymer matrix, and the mass transport of the molecules and polymer during the holographic recording.

\section{ACKNOWLEDGEMENTS}

The authors thank Dr. E. Markava for the help in synthesising the azobenzene derivatives and in discussions of the results.

This work is supported by the National Research Programme in Material Sciences of Latvia (2005-2009). 


\section{REFERENCES}

1. Rau, H. (2002). Photoisomerization of Azobenzenes (in: Photorefractive organic films, eds. Z. Sekkat, W. Knoll) San Diego: Academic Press, pp. 3-47.

2. Oliveira, O.N. (Jr.), don Santos, D.S. (Jr.), Balogh, D.T., Zucolotto, V., \& Mendoça, C.R. (2005). Optical storage and surface-relief gratings in azobenzene-containing nanostructured films. Adv. Colloid Interface Science, 116, 179-192.

3. Natansohn, A., \& Rochon, P.L. (2002). Photoinduced motions in azo-containing polymers. Chem. Rev., 102, 4139-4175.

4. Fiorini, C., Prudhomme, N., Veyrac, G,de, Maurin, I., Raimond, P., \& Nunzi, J.-M. (2000). Molecular migration mechanism for laser induced surface relief grating formation. Synthetic Metals, 115, 121-125.

5. Markava, E., Gustina, D., Muzikante, I., Gerca, L., Tokmakov, A., Fonavs, E., Stiller, B., \& Brehmer, L. (2003). Optical properties of some novel azobenzenes in thin layers. SPIE Proceedings, 5122, 210-215.

6. Brode, W.R., Gould, J.H., \& Wyman, G.M. (1952). The relation between the absorption spectra and the chemical constitution of dyes. XXV. Phototropism and cistrans isomerism in aromatic azo compounds. J. Am. Chem. Soc., 74, 4641-4646.

7. Niparte, B., Muzikante, I., Fonavs, E., \& Gustina, D. (2010). Photoisomerization process of azobenzene compounds in thin polymer films. Latv. J. Phys. Tec. Sci., 47 (3), 5-12.

8. Tripathy, S.K., Viswanathan, N.K., Balasubramanian, S., \& Kumar, J. (2000). Holographic fabrication of polarization selective diffractive optical elements on azopolymer film. Polym. Adv. Technol., 11, 570-574.

9. Clayden, J. Greeves, N., Warren, S., \& Wothers, P. (2000). Organic Chemistry $\left(1^{\text {st }}\right.$ ed-n). Oxford: Oxford University Press.

\section{OPTISKI IEROSINĀTIE VIRSMAS RELJEFA REŽĢI POLIMĒRA KĀRTIN̦Ā AR SULFONILGRUPU SATUROŠĀM AZOBENZOLU MOLEKULĀM}

\section{E. Laizane, D. Gustina, K. Kundzins, I. Muzikante, J.T eteris}

$\mathrm{K}$ o p s a vi $1 \mathrm{k} \mathrm{u} \mathrm{m} \mathrm{s}$

Starp organiskiem materiāliem hologrāfijai nozīmīgu vietu ieņem azobenzola atvasinājumi. Īpaši tas attiecas uz polimēriem, kuros azobenzola grupas ir sānu ķēdē. Šajos polimēros novēro gan fotoierosinātu dubultlaušanu, gan hologrāfisku ierakstu un virsmas reljefa režğa veidošanos. Ierosinot azobenzola molekulu fotoizomerizācijas absorbcijas joslās, notiek tās ǵeometrijas maiņa. Pat ja azobenzola grupa nav piesaistīta, bet kā atsevišķas molekulas ir iemaisītas polimēra matricā, tās izraisa dažādu fizikālu procesu izmaiņas.

Šajā darbā ir pētīiti hologrāfiskais ieraksts un virsmas reljefa veidošanās polimēru plēvìtē ar origininālām azobenzolu molekulām. Hologrāfiskais ieraksts tika veikts saimnieka - viesa sistēmai, kur saimnieks ir PMMA un viesis ir A-45 vai A48 molekulas. Ierakstam izmantots $325 \mathrm{~nm}$ viḷna garumu lāzers. $325 \mathrm{~nm}$ atrodas galvenās trans-izmēra absorbcijas joslas īso viḷnu garuma pakājē, kur dominē trans $\rightarrow$ cis fotoizomerizācija. Ieraksta sākumā difrakcijas efektivitātes palielināšanos varētu izskaidrot ar cis - trans fotoizomerizāciju. Otru lielāko pieaugumu var saistīt ar virsmas reljefa veidošanos. Sistēmā ar A-45 molekulām tika iegūta difrakcijas efektivitāte $0.7 \%$, bet A-48 molekulām - 0.24\%. Polimēra kārtin̄ās ar A-45 molekulām ir iespējama labāka azobenzola molekulu un polimēra masas pārnese, ko varētu saistìt ar pašas molekulas struktūru. 